\title{
Using an unmanned aerial vehicle (UAV) for lake management: ecological status, lake regime shift and stratification processes in a small Mediterranean karstic lake
}

\author{
Jose Luis Moreno ${ }^{1,}{ }^{*}$ (D) , Jose Fernando Ortega ${ }^{2}$ (D), Miguel Ángel Moreno ${ }^{2}$ (D) and Rocío \\ Ballesteros $^{2}$ iD \\ ${ }^{1}$ University of Castilla-La Mancha. Regional Centre of Water Research. Crtra. de las Peñas, km 3, Albacete \\ 02071, Spain. \\ 2 Universty of Castilla-La Mancha. Institute for Regional Development. Campus Universitario s/n, Albacete \\ 02071, Spain. \\ * Corresponding author: joseluis.moreno@uclm.es
}

Received: 16/02/21 Accepted: 21/09/21

\begin{abstract}
Using an unmanned aerial vehicle (UAV) for lake management: ecological status, lake regime shift and stratification processes in a small Mediterranean karstic lake

High-resolution remote sensing imagery by unmanned aerial vehicles (UAVs) has been used as a tool for the environmental management of natural resources. Monitoring programmes that evaluate the ecological status of water bodies according to the Water Framework Directive (WFD) involve significant costs and sampling efforts that can be reduced by using UAVs. UAV imagery was used to measure some metrics of the "macrophytes and phytobenthos" biological quality element (BQE), which is required to assess the ecological status of European lakes; e.g. the percentage cover of hydrophytes and helophytes. Eight UAV flights took place during an annual cycle (July 2016 to July 2017) in a small karstic lake located in southeast Spain. Limnological surveys of physicochemical (temperature, conductivity, dissolved oxygen, $\mathrm{pH}$ ) and biological (pigments) parameters were simultaneously performed to correctly interpret the UAV images. For each flight performance, an orthomosaic of georeferenced RGB images was obtained, and the different features of interest were monitored and quantified by an automated identification and classification system (the LAIC software). The UAV images allowed us to not only evaluate the lake's ecological status by measuring macrophyte metrics, but to also detect relevant ecological events for environmental management. A gradual burial process of charophyte meadows by the proliferation of periphytic cyanobacterial was detected in an early state by UAV images. Stratification processes, such as hypolimnetic sulphur bacteria blooms or metalimnetic white colloidal layers, were also observed by UAV imaging. We conclude that UAV imagery is a useful tool for environmental lake management.
\end{abstract}

Key words: macrophytes, charophytes, cyanobacteria, lake regime shift, purple sulphur bacteria, anoxia, hypolimnion

\section{RESUMEN}

Uso de un vehículo aéreo no tripulado (VANT) para la gestión de lagos: estado ecológico, cambio de régimen y procesos de estratificación en una pequeña laguna cárstica mediterránea

La teledetección de alta resolución obtenida mediante vehículos aéreos no tripulados (VANTs), viene siendo utilizada como herramienta en la gestión de los recursos naturales. Los programas de seguimiento para evaluar el estado ecológico de las masas de agua según la Directiva Marco del Agua suelen implicar altos costes y esfuerzos de muestreo, que podrían reducirse utilizando VANTs. En el presente estudio, se han utilizado las imágenes obtenidas con VANTs para medir algunas métricas del elemento biológico "macrófitos y fitobentos" requeridas en la evaluación del estado ecológico de los lagos europeos, como son el porcentaje de cobertura de hidrofitos y helófitos. El estudio se llevó a cabo en un pequeño lago cárstico del sureste de España, donde se realizaron un total de ocho vuelos durante un ciclo anual (julio de 2016 a julio 2017). Para interpretar correctamente las imágenes obtenidas con VANTs, simultáneamente se registraron algunos parámetros limnológicos fisicoquimicos (temperatura, conductividad, oxigeno disuelto, $\mathrm{pH}$ ) y biológicos (pigmentos). Para cada vuelo se obtuvo un ortomosaico 
de imágenes $R G B$ georreferenciadas, y se identificaron y cuantificaron los diferentes elementos de interés mediante un sistema automático de identificación y clasificación. Las imágenes obtenidas permitieron no solo evaluar el estado ecológico del lago sino también detectar procesos ecológicos relevantes para la gestión del lago. Por ejemplo, se detectó en estado temprano un proceso de enterramiento de las praderas de carófitos por la proliferación de tapetes perifíticos de cianobacterias. Adicionalmente, se detectaron procesos de estratificación como la formación de blooms de bacterias púrpuras del azufre en el hipolimnion, o de capas coloidales de color blanco en el metalimnion. Se puede concluir que las imágenes obtenidas con VANTs pueden ser herramientas útiles en la gestión medioambiental de los lagos.

Palabras clave: macrófitos, carófitos, cianobacterias, cambio de régimen, bacterias púrpuras del azufre, anoxia, hipolimnion

This is an open-access article distributed under the terms of the Creative Commons Attribution-NonCommercial 4.0 International (CC BY-NC 4.0) License.

\section{INTRODUCTION}

On 23 October 2000, "Directive 2000/60/EC of the European Parliament and Council established a framework for Community action in the water policy field" or, in short, the EU Water Framework Directive (WFD) was published. It establishes how to evaluate the ecological status of water bodies by means of biological quality elements (BQEs), and the hydromorphological and physicochemical elements supporting biological elements. For lakes, four BQEs are proposed: phytoplankton, other aquatic flora (macrophytes and phytobenthos), benthic invertebrate fauna and fish fauna. Implementing the WFD requires developing methodologies and protocols to evaluate community composition and abundance. This requirement has promoted the use of UAV imagery to evaluate the different metrics needed to assess the ecological status of water bodies (e.g. Hunter et al., 2010, Kubiak et al., 2016, Venturi et al., 2016, Rivas et al., 2017). These studies agree with methodologies based on the notion that performing aerial flights, supported by reduced fieldwork, might decisively contribute to the assessment and monitoring of water body status.

The importance of submerged macrophytes, mainly vascular hydrophytes and macroalgae, for a good ecological status relies on their key functional role to stabilise and promote excellent environmental conditions in water bodies. Extensive submerged macrophyte growth is often associated with clear water conditions because they constraint nutrients on phytoplankton, increase zooplankton grazers, decrease sediment resuspension and possibly secrete allelopathic substances (Jeppesen 1998, Van der Berg et al., 1998). Moreover, submerged macrophytes are absolutely involved in nutrient cycling regulation, immobilization of waterborne pollutants and the provision of physical habitats for other aquatic biota (Krupska et al., 2012, Scheffer et al., 1993, Scheffer \& Carpenter 2003, Scheffer \& Jeppesen 2007). Macrophytes' abundance and diversity are important indicators of the ecological status of shallow lakes and are widely used as metrics for site-condition monitoring (Hunter et al., 2010). Furthermore, the elimination of submerged macrophytes usually leads to an ecological shift in shallow lakes from a clear water state to a turbid state (Scheffer et al., 1993). Biotic and abiotic factors can be involved in this environmental shift through diverse mechanisms (Scheffer et al., 2001).

Remote sensing imagery by UAVs has very quickly evolved in the last decade and is now a useful tool for environmental management, agriculture, river and lake basin planning, etc. (Zhang \& Kovacs, 2012, Nex \& Remondino, 2014, Koparan, 2016), The gradual reduction in the acquisition and exploitation costs of UAV platforms, along with the higher imagery resolution compared to the low or medium remote sensing platforms traditionally used as satellites (Jones \& Gross, 2014), have made their use more widespread (Colomina \& Molina, 2014). For example, studies like those by DeBell et al. (2016) and Koparan (2016) have focused on using UAV imagery for hydrological management and water body characterisation.

Many studies have been published about assessing river water body status using UAV imagery (Rhee et al., 2017). They have addressed a variety of aspects, such as the hydromorphological characterisation of rivers (Rivas et al., 2015, 
2016, 2017, Woodget et al., 2017), riparian and aquatic vegetation (Husson et al., 2013, Ghazal et al., 2015) or algae blooms (Flynn \& Chapra, 2014, Hu et al., 2015, Kudela et al., 2015). Satellite imagery is more widely used than UAV imagery, arguably because of the ease of data acquisition (downloading or purchasing instead of conducting full field campaigns), its historic availability, affordability, etc. (e.g. in Spain, Doña et al., 2014, Sòria-Perpinyà et al., 2019). Moreover, larger areas can be covered by low and medium remote sensing platforms, such as satellites, compared to UAVs because of the lower resolution employed. However, the spatial scale of satellite imagery can be insufficient for some limnological and vegetation applications. Therefore, applying the WFD to lakes has recently promoted studies that use spatial high-resolution remote sensing imagery by UAVs, albeit as preliminary approaches to assist limnological assessments (Rhee et al., 2017). Thus, some works have addressed a range of limnological aspects that are involved in ecological status using UAV imagery; for example, dynamics of helophytes (Phragmites) in lakes (Venturi et al., 2016, Meneses et al., 2018, Tóth, 2018), submerged macrophytes in shallow lakes (Hunter et al., 2010) or algae blooms in reservoirs and lakes (Kubiak et al., 2016, Kageyama et al., 2018). Thus, combining aerial imagery with some limnological support provides a holistic approach to assess lake status.

In this work, we used UAV imagery to monitor and quantify aquatic vegetation cover to evaluate the ecological status of a small karstic lake. Additionally, UAV imagery detected some relevant ecological processes and events for lake environmental management and risk assessment purposes.

\section{MATERIALS AND METHODS}

\section{Study area}

Lake Alboraj is a permanent small karstic lake with a 3-hectare (ha) surface located in southeast Spain (Fig. 1). Currently, its water table extends 0.5 ha, although the water level fluctuates and very much depends on the precipitation regime. Nevertheless, the lateral groundwater inputs from a local shallow mio-plioquaternary aquifer with low-medium permeability materials (gypsum, conglomerates, sandstones, clayey limestones, tuffs and travertines) prevent drying ((IGME, 2009, CHS, 2016). The lake came about from a combination of tectonic and karstic processes
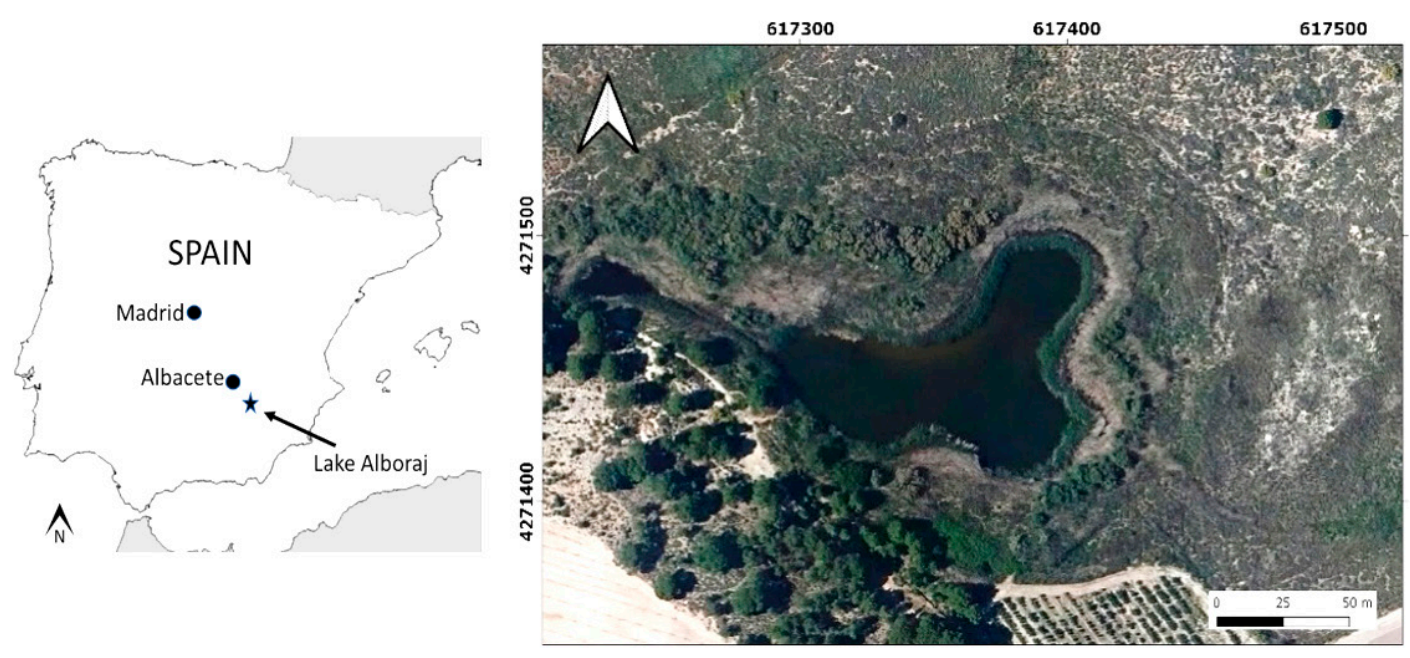

Figure 1. Geographical location of Lake Alboraj in southeast Spain. (image from 2018 PNOA flight, Instituto Geográfico Nacional, http://fototeca.cnig.es). Grid: EPSG: 25830-ETRS89/UTM zone 30N. Localización geográfica de la Laguna de Alboraj en el sureste de España (imagen del vuelo PNOA 2018, Instituto Geográfico Nacional, http://fototeca.cnig.es). Retícula: EPSG: 25830-ETRS89/ UTM zone $30 \mathrm{~N}$. 
Table 1. Ionic composition of the Lake Alboraj surface (1 m deep) water (31/08/2016). Composición iónica del agua superficial (1 m) de la Laguna de Alboraj (31/08/2016).

\begin{tabular}{lr}
\hline & $\mathrm{mS} / \mathrm{cm}$ \\
\hline Conductivity & 11.5 \\
\hline Ionic composition & $\mathrm{mg} / 1$ \\
\hline $\mathrm{HCO}_{3}{ }^{-}+\mathrm{CO}_{3}{ }^{-2}$ & 132.0 \\
$\mathrm{SO}_{4}^{-2}$ & 7055.8 \\
$\mathrm{Cl}^{-}$ & 1354.4 \\
$\mathrm{Ca}^{+2}$ & 768.2 \\
$\mathrm{Mg}^{+2}$ & 1126.0 \\
$\mathrm{Na}^{+}$ & 550.7 \\
$\mathrm{~K}^{+}$ & 30.4 \\
\hline
\end{tabular}

(Rodríguez-Pascua et al., 2012, JCCM, 2015). The lake resembles shallow lakes, but its morphometry includes three deep dolines where water column stratification occurs. The maximum depth in its deeper doline fluctuates between 4-6 metres. Shallow areas outside the dolines (interdoline area) are the available colonisable substratum for charophyte meadows (Chara hispida), whereas the bottom of dolines is devoid of charophytes. No water extraction or sewage discharges occur in this lake.

This lake has been classified as type 3190 Lakes of gypsum karst (Natural Habitat Types of Community Interest, Habitat Directive 92/43/ EEC) (Camacho et al., 2009) because it is on, and surrounded, by a gypsum-rich lithology. In line with the WFD, the lake is classified as national type "L-T15: Karstic, evaporites, hypogenic or mix, small". Like other Spanish karstic lakes that

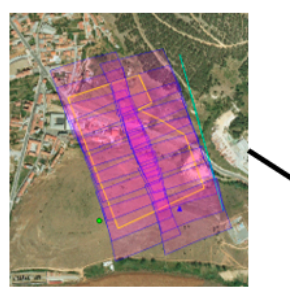

1. Flight planning Required resolution and camera Selection of flight area:

- Take-off and landing site

- Direction of the flight

- Overlapping (60\% forward and $40 \%$ side lapping) Computation of flight height and duration of the flight Design strategy of GCPs location

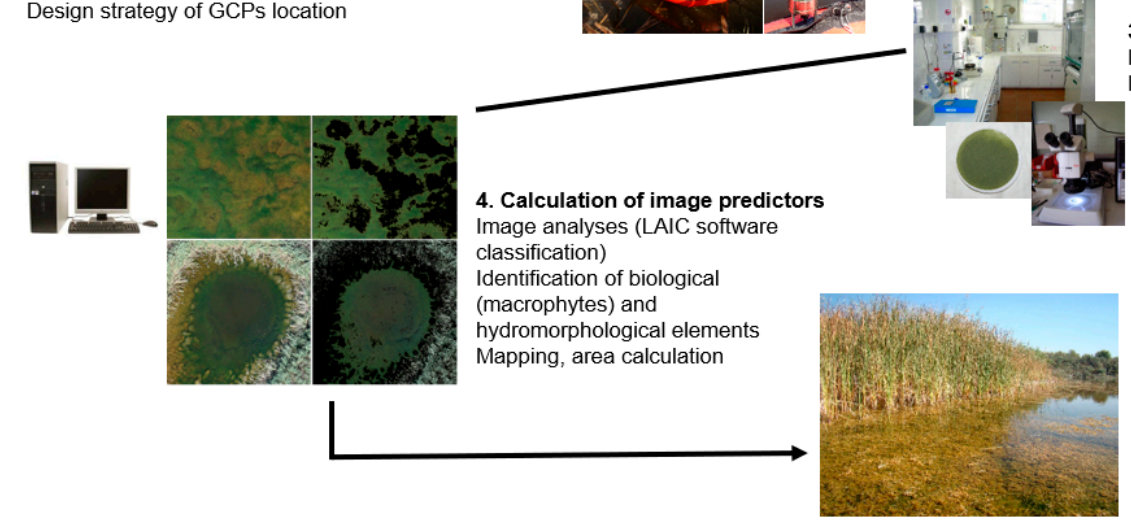

2. Flight and data collection

Weather condictions (wind, cloud, etc.)

Distribution of GCPs

Flight performance and image acquisition

Measurement of the GCPs (RTK GPS)

Distribution sampling points

Limnological survey
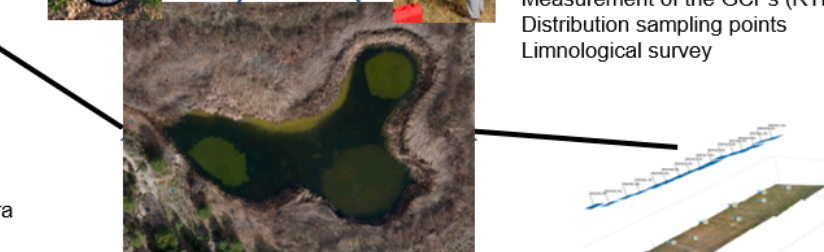

3.1. Photogrammetry

Automatic selection of non-

blurred images

Photogrammetric workflow:

- Alignment of photos

- Building dense cloud

- Building mesh

- Building texture

3.2. Lab work

Physichochemical analyses

Biological analyses

Figure 2. Flow chart including the main image acquisition and analysis phases followed to obtain the geomatic product. GCP, ground control point; RTK GPS, real-time kinematic global position system. Proceso de adquisición de imágenes y fases de análisis seguidos para la obtención del producto geomático. GCP, punto de control; RTK GPS, sistema cinemático de posicionamiento global en tiempo real. 
come into contact with gypsum layers, the gypsum-rich substratum provides the lake water with a high sulphate concentration, which has a magnesium-sulphated ionic composition and high conductivity values ranging from 9 to $12 \mathrm{mS} / \mathrm{cm}$ (Table 1).

Lake Alboraj is located in a Special Area of Conservation (SAC) of the European Natura Network named "Saladares de Cordovilla y Agramón y Laguna de Alboraj" (code ES4210011). The main natural SAC values include singular halophytic flora, and highlight the local endemic of the SAC Helianthemum polygonoides (Cistaceae), which occurs in the lake's immediate surroundings. The lake basin is in an agricultural landscape where eutrophication, salinisation and a lowering water level are the main anthropic impacts (Moreno et al., 2018). Submerged macrophytes, helophytes and phytoplankton produce organic matter that accumulates in sediments, whose decomposition promotes dystrophic characteristics (Valiente et al., 1997). The lake is surrounded by a reed belt of Phragmites australis and Thypha dominguensis, and the tamarisk Tamarix canariensis on the outer band.

\section{Obtaining high-resolution UAV images}

Very high-resolution ( 2.5 centimetres) aerial images in the RGB (Red, Green, Blue) visible spectrum were collected. The employed platform was a quadcopter md4-1000 (Microdrones, Inc., Kreuztal, Germany), a 1.00-meter diameter (from rotor hub to rotor hub) quadcopter with a 0.224-kilogram embedded camera, a total payload capacity of $1.2 \mathrm{~kg}$ and a maximum take-off weight of $6 \mathrm{~kg}$. This equipment tolerates wind gusts of $6 \mathrm{~m} / \mathrm{s}$. A Sony Alpha ILCE-5100 camera (Sony Corporation, Tokyo, Japan) with a 24.3 MPix resolution was employed. Figure 2 depicts the flow chart, including the main image acquisition and analysis phases followed to obtain a useful geomatic product for assessing macrophyte covers. From it, the ecological status was calculated.

The ground sampling distance (GSD) was calculated to obtain a target imagery resolution of $2.5 \mathrm{~cm}$ based on the camera focal length by considering a maximum flight altitude of $120 \mathrm{~m}$ according to the regulatory airspace constraints in
Spain. Ten targets (radius of $0.20 \mathrm{~m}$ ) were uniformly located and measured in the flight area to obtain the final geo-referenced images (orthoimages) (Ballesteros et al., 2018). The location of the targets' centroids was measured by a Leica global position system (GPS) 1200 (Leica Geosystems AG, Heerbrugg, Switzerland) linked with a global navigation satellite system (GNSS) permanent reference station (ERGNSS, 2008). The estimated GNSS real-time kinematic (GNSS-RTK) system accuracy was $0.02 \mathrm{~m}$ for planimetry and $0.03 \mathrm{~m}$ for altimetry.

Flights and image processing were performed according to the methodology proposed by Córcoles et al. (2013) and Hernández-López et al. (2013). Eight UAV flights took place during an annual cycle, from July 2016 to July 2017. Flights started around solar noon to minimise solar glints and shading, and to optimise the water table and submerged vegetation visibility conditions, as well as maximum deep water column visibility. Image processing included the automatic selection of non-blurred images and the following photogrammetric workflow: alignment of photos, building dense cloud, building mesh, building texture. For each flight, an orthomosaic of the georeferenced RGB images was generated for the main purpose of quantifying the total macrophytes coverage in the lake.

\section{Interpreting UAV images}

The areas covered by aquatic macrophytes were delimited using the Leaf Area Index Calculation (LAIC) classification software. The LAIC software is a MATLAB-based supervised artificial neural network (ANN) interface designed to discriminate green canopy cover from ground, shadows, and other background features by high-resolution UAV imagery (Córcoles et al., 2013). This software performed a cluster classification based on CIELAB characteristics. A k-means clustering algorithm of the RGB levels on the $L^{*} a^{*} b *$ colourspace transformed imagery was then implemented. The analysis groups pixels into k-clusters (k) with similar red/green (a) and yellow/blue (b) values. L (lightness) was not taken into account by the clustering algorithm. The number of clusters $(\mathrm{k})$ depends on the feature being identified 


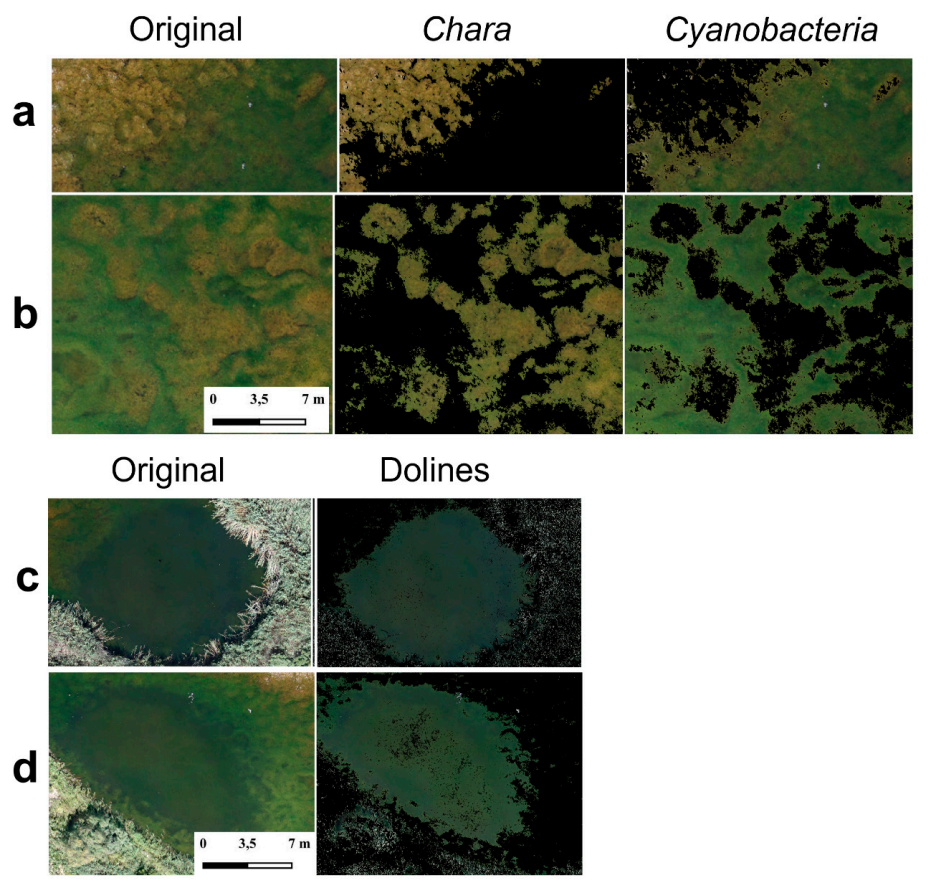

Figure 3. Example of the class delineation of some features of interest obtained from the classification method (LAIC software). a) and b) Selection of Chara and Cyanobacteria from the original orthoimage obtained by high-resolution UAV imagery. c) Selection of the SE doline; d) Selection of the SW doline. Date of the original image: 26/07/2016 (Fig. 4). Ejemplo de la delimitación de clases de algunos elementos de interés producido por el método de clasificación (LAIC). a) y b) Selección de Chara y Cyanobacteria a partir de la ortoimagen original obtenida por las imágenes de alta resolución captadas por VANTs. c) Selección de los límites de la dolina SE; d) Selección de los límites de la dolina SO.

and was determined following an iterative process that increased $\mathrm{k}$ by one up to a maximum of ten clusters until visually satisfactory results were obtained. In this context, any visually satisfactory results required the image outputs to show that the feature of interest had been adequately identified. This supervised method was used to calibrate an artificial neural network (ANN) and the remaining images.

\section{Ecological status}

In Spain, several metrics have been proposed in the Spanish protocol to evaluate the ecological status of lakes by means of the BQE "other aquatic flora" (macrophytes and phytobenthos) (MAGRAMA, 2013a, 2013b). We used UAV imagery to measure two main macrophyte metrics that are proposed in the Spanish protocol for lake type L-T15:
1) Hydrophyte cover (\%). This metric assesses the cover percentage of type-characteristic hydrophytes on the colonisable substratum; that is, in zones where its settlement is possible. The characteristic hydrophyte species for type L-T15 are listed in the Spanish protocol (MAGRAMA 2013a). Chara hispida, the only hydrophyte species that inhabits the lake, is on that list. Examples of delimitation of the areas covered by Chara hispida by the LAIC classification software are shown in figure $3 \mathrm{a}$ and $3 \mathrm{~b}$. The total area covered by Chara corresponds to the absolute hydrophyte cover in the lake $\left(\mathrm{m}^{2}\right)$. The cover percentage of hydrophytes is referred to as the "colonisable substratum" (according to the Spanish protocol, areas less than $2 \mathrm{~m}$ deep, slopes $<30 \%$, and nonrocky substratum) which, in the studied lake, corresponded to the whole shallow areas outside the three dolines (i.e. the interdoline area). The interdoline area was calculated by subtracting the 
total area occupied by the three dolines from the total water table area. Examples of the doline areas delimited by the LAIC classification software are shown in figure $3 \mathrm{c}$ and $3 \mathrm{~d}$.

Cyanobacterial mats covered (buried) part of the charophyte meadows. The cover percentages of cyanobacterial mats were also measured in the same way as charophytes. Examples of the cyanobacterial mats delimited by the LAIC software classification are shown in figure $3 \mathrm{a}$ and $3 \mathrm{~b}$.

2) Helophyte cover (\%). This metric assesses the cover percentage of type-characteristic helophytes on lake shores where its settlement is possible (MAGRAMA 2013a). With the studied lake, the whole lake's perimeter was colonisable for the type-characteristic species Phragmites australis and Thypha domingensis. The UAV images verified that $100 \%$ perimeter was colonised by helophytes on all the dates and, therefore, it was not necessary to use the LAIC software to calculate the value of this metric.

In order to calculate ecological status, the values obtained for the two metrics were compared to the reference values provided by national legislation (Table 2; MAGRAMA, 2015). The deviation of the metric values from the reference values set

Table 2. Reference values and the EQR (Ecological Quality Ratio) limit values between the ecological status classes for the two metrics addressed by UAV image processing (MAGRAMA 2015; lake type "L-T15: Karstic, evaporites, hypogenic or mix, small"). Valores de referencia y de valores límite de EQR (Ratio de Calidad Ecológica) entre clases de estado ecológico para las dos métricas estimadas mediante el procesado de imágenes obtenidas con VANTs.

\begin{tabular}{lcc}
\hline & \multicolumn{2}{c}{ Macrophyte metrics } \\
\hline & $\begin{array}{c}\text { Hydrophyte } \\
\text { cover (\%) }\end{array}$ & $\begin{array}{c}\text { Helophyte } \\
\text { cover (\%) }\end{array}$ \\
\hline Reference value & 90 & 100 \\
EQR High/Good & 0.83 & 0.9 \\
EQR Good/ Moderate & 0.55 & 0.75 \\
EQR Moderate/ Poor & 0.28 & 0.3 \\
EQR Poor/ Bad & 0.01 & 0.1 \\
\hline
\end{tabular}

out in national legislation was calculated by the Ecological Quality Ratio (EQR; European Communities, 2003): observed value/reference value, with values ranging from 0 (bad status) to 1 (high reference status). The EQR limit values among the five ecological status classes (high/good/moderate/poor/bad) were also obtained from national legislation (Table 2; MAGRAMA, 2015).

\section{Limnological assessment}

Sampling dates were chosen as closely to the flights as possible to correctly interpret the UAV orthoimages (Table 3). To validate the correspondence between submerged macrophytes and UAV images, field observations were made from a boat. At the beginning, halfway and at the end of the study period, a rake was used to extract charophytes from several points around the three dolines (two or three points per doline) for species confirmation. To establish a correspondence between images and the stratification features occurring in dolines, physicochemical and biological profilings were done from a boat at the deepest lake point (SE doline). Dissolved oxygen, water temperature, $\mathrm{pH}$ and conductivity were measured

Table 3. Flight and limnological sampling dates. Fechas de los vuelos VANT y de los muestreos limnológicos.

\begin{tabular}{cc}
\hline Flight dates & Sampling dates \\
\hline $26 / 07 / 2016$ & $14 / 07 / 2016$ \\
$23 / 08 / 2016$ & $25 / 08 / 2016$ \\
$05 / 10 / 2016$ & $11 / 10 / 2016$ \\
$27 / 10 / 2016$ & $08 / 11 / 2016$ \\
$22 / 02 / 2017$ & $07 / 03 / 2017$ \\
$10 / 05 / 2017$ & $11 / 05 / 2017$ \\
$22 / 06 / 2017$ & $12 / 06 / 2017$ \\
$12 / 07 / 2017$ & $18 / 07 / 2017$ \\
\hline
\end{tabular}




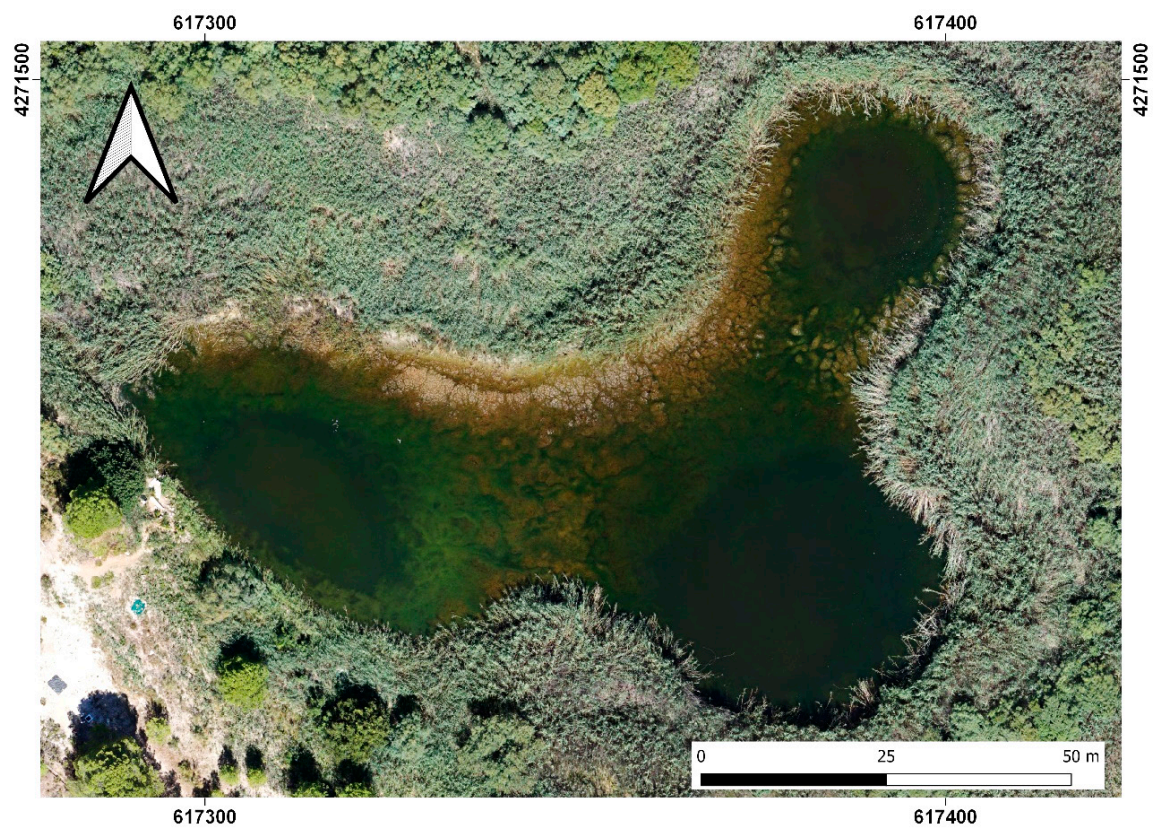

Figure 4. The first high-resolution orthoimage obtained by the UAV imagery system (26/07/2016). Grid: EPSG: 25830-ETRS89/UTM zone $30 \mathrm{~N}$. At the bottom of the lake, brown corresponds to the submerged charophyte meadow and bright green denotes cyanobacterial mats. La primera ortoimagen de alta resolución obtenida a partir de las imágenes captadas por VANTs (26/07/2016). Respecto al fondo del lago, el color marrón corresponde a la pradera sumergida de carófitos y el verde brillante a tapetes de cianobacterias. Retícula: EPSG: 25830-ETRS89/UTM zone 30N.

at 0.5 metre-depth intervals using adequate probes (Hach HQd multiparametric portable meter). Water samples were taken with a Rüttner bottle at a 1 metre-depth interval for the pigment analyses to detect vertical phytoplankton stratification as a possible element to be captured by UAV images. Phytoplankton chlorophyll $a$ and bacteriochlorophyll $a$ were determined by filtering a big enough volume to obtain a coloured filter (between 200$1000 \mathrm{ml}$ depending on the sample) through fibreglass filters $(0.7 \mu \mathrm{m}$ pore size, $47 \mathrm{~mm}$ diameter $)$ and using a vacuum pump. Filters were placed inside $15 \mathrm{ml}$ screw-capped polypropylene tubes covered by aluminium foil and frozen at $-20{ }^{\circ} \mathrm{C}$ for 1 week to break algal cells. Pigment extraction was done in the same tube with the filter by adding $5 \mathrm{ml}$ of $90 \%$ acetone and leaving it in the fridge in the dark at $4{ }^{\circ} \mathrm{C}$ overnight. After performing spectrophotometric scanning (in semidarkness conditions) within the $350-850 \mathrm{~nm}$ range, chlorophyll $a$ was calculated by the formula below (Jeffrey and Humphrey 1975):

$$
\begin{gathered}
\mathrm{Chl} a\left(\mathrm{mg} / \mathrm{m}^{3}\right)=[11.85(\mathrm{~A} 664-\mathrm{A} 750)- \\
1.54(\mathrm{~A} 647-\mathrm{A} 750)-0.08(\mathrm{~A} 630-\mathrm{A} 750)] \cdot \mathrm{V} / \mathrm{V} \cdot \mathrm{Z}
\end{gathered}
$$

where A630, A647, A664 and A750 are the absorbance values at the indicated wavelength; $\mathrm{v}$ is the volume of added acetone $(\mathrm{ml}) ; \mathrm{V}$ is the volume of filtered water (L); $\mathrm{Z}$ is cuvette width (cm). The bacteriochlorophyll a concentration (measurement of the abundance of purple sulphur bacteria) was calculated by this formula (Tachahasi \& Ichimura, 1970):

$$
\mathrm{Bchl} a\left(\mathrm{mg} / \mathrm{m}^{3}\right)=[25.2(\mathrm{~A} 772-\mathrm{A} 830)] \cdot \mathrm{v} / \mathrm{V} \cdot \mathrm{Z}
$$

Observation and taxonomic approach of purple sulphur bacteria were addressed by a light microscope (Olympus BX50) equipped with a digital camera (Leica DFC420C). Water transparency was also measured at the profiling point (SE doline) with a Secchi disc. Additional chemical analyses of major ions were performed (Laboratorio Aguas de Albacete; certified municipal laboratory): alka- 
Table 4. Ecological status calculated from the macrophyte metrics hydrophyte cover and the helophyte cover. The cover of cyanobacterial mats is also included in the first column. EQR: Ecological Quality Ratio (observed value/reference value; see Table 1 for the reference values and limit values of $\mathrm{EQR}$ between the ecological status classes). Estado ecológico calculado a partir de las métricas cobertura de hidrofitos y cobertura de helófitos. En la primera columna también se incluye la cobertura de cianobacterias. EQR: Ratio de Calidad Ecológica (valor observado/valor de referencia; ver Tabla 1 para los valores de referencia y valores límite entre clases de estado ecológico).

\begin{tabular}{cccccccc}
\hline & & \multicolumn{3}{c}{ Hydrophytes } & \multicolumn{3}{c}{ Helophytes } \\
\hline Dates & $\begin{array}{c}\text { Cyanobacterial } \\
\text { mats (\%) }\end{array}$ & $\begin{array}{c}\text { Hydrophyte } \\
\text { cover (\%) }\end{array}$ & EQR & $\begin{array}{c}\text { Ecological } \\
\text { status }\end{array}$ & $\begin{array}{c}\text { Helophyte } \\
\text { cover (\%) }\end{array}$ & EQR & $\begin{array}{c}\text { Ecological } \\
\text { status }\end{array}$ \\
\hline $26 / 07 / 2016$ & 72.4 & 27.6 & 0.31 & Moderate & 100 & 1 & High \\
$23 / 08 / 2016$ & 63.9 & 23.6 & 0.26 & Poor & 100 & 1 & High \\
$05 / 10 / 2016$ & 72.4 & 24.1 & 0.27 & Poor & 100 & 1 & High \\
$27 / 10 / 2016$ & 76.6 & 20.7 & 0.23 & Poor & 100 & 1 & High \\
$22 / 02 / 2017$ & 73.1 & 15.9 & 0.18 & Poor & 100 & 1 & High \\
$10 / 05 / 2017$ & 83.8 & 9.0 & 0.10 & Poor & 100 & 1 & High \\
$22 / 06 / 2017$ & 90.2 & 4.6 & 0.05 & Poor & 100 & 1 & High \\
$12 / 07 / 2017$ & 90.6 & 4.6 & 0.05 & Poor & 100 & 1 & High \\
\hline
\end{tabular}

linity by acid titration (precision $\pm 0.1 \%$ ); calcium and magnesium by flame atomic absorption spectrometry $( \pm 19 \%)$; chloride and sulphate by ionic chromatography ( $\pm 5.9 \%)$; sodium and potassium by flame atomic emission spectrometry $( \pm 11.7 \%)$. Redox potential was measured with a Hach Intellical MTC101 rugged probe coupled to a Hach HQd multiparametric portable meter. Sulphide $\left(\mathrm{H}_{2} \mathrm{~S}\right)$ was measured with a Hach Hydrogen Sulphide Test Kit HS-WR (223801), which is based on the methylene blue method (precision $0.5 \mathrm{mg} / \mathrm{l}$ ).

\section{RESULTS AND DISCUSSION}

\section{Hydromorphological features}

The UAV images revealed the lake's bathymetric characteristics, with the presence of three circular

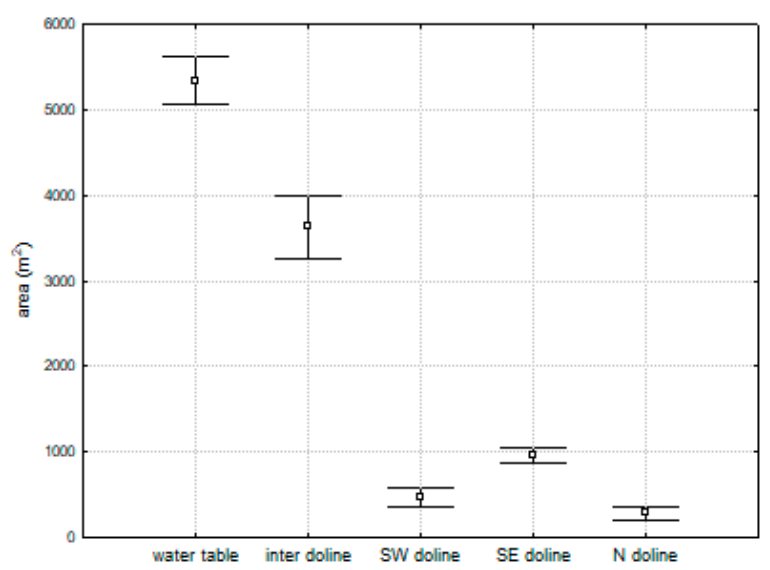

Figure 5. Mean surface areas $\left(\mathrm{m}^{2}\right)$ and standard errors of the selected hydromorphological features at Lake Alboraj during the study period $(\mathrm{n}=8)$. Valores medios y desviación típica del área $\left(m^{2}\right)$ ocupada por los elementos hidromorfológicos medidos en la Laguna de Alboraj durante el periodo de estudio $(n=8)$. 
dolines or sinkholes located to the north, southwest and southeast of the lake (Fig. 4). The SE doline obtained both the highest area and depth values, while the $\mathrm{N}$ doline was the smallest and

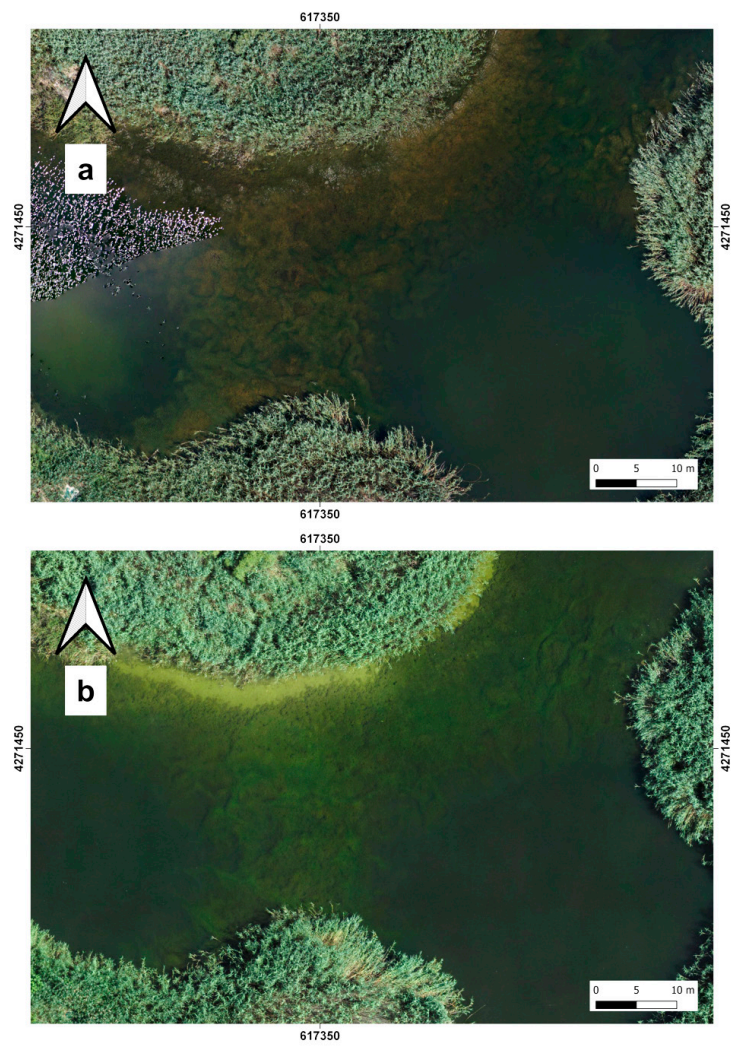

Figure 6. A comparison of the burial process of charophyte meadows by the cyanobacterial mats at Lake Alboraj at the beginning and the end of the study period. a) at the beginning of the study period (26/07/2016), $72.4 \%$ of Chara meadow was covered by cyanobacterial mats, and $27.6 \%$ of the Chara meadow remained free of cyanobacteria (see Table 4). b) at the end of the study period $(12 / 07 / 2017)$, charophyte burial was almost complete with $90.6 \%$ of the Chara meadow covered by cyanobacterial mats, and $4.6 \%$ of the remaining Chara free of cyanobacteria. Brown corresponds to the charophyte meadow and green to cyanobacterial mats. Comparación del proceso de enterramiento de las praderas de carófitos por los tapetes de cianobacterias en la Laguna de Alboraj, al principio y final del periodo de estudio. a) al principio (26/07/2016) el 72.4\% de la pradera de Chara estaba cubierta por tapetes de cianobacterias y el $27.6 \%$ quedaba libre de tapetes (ver Tabla 4). b) al final del periodo de estudio (12/07/2017) el proceso de enterramiento era casi completo, con el $90.6 \%$ de la pradera de Chara cubierta por tapetes de cianobacterias y el $4.6 \%$ libre de cianobacterias. El color marrón corresponde a la pradera de carófitos y el verde a los tapetes de cianobacterias. shallowest. Although morphological features like dolines tended to logically remain constant on the study's time scale, slight interdate variation in the doline delimitation was recorded by the LAIC software classification. Conversely, the water table and interdoline area showed higher temporal variation due to seasonal water level fluctuation. The mean interdoline area value (the available substratum for charophytes) was $3631.8 \mathrm{~m}^{2}$; i.e. $67.9 \%$ of the water table (Fig. 4, 5).

\section{Ecological status}

In this study, UAV imagery was used to measure some features related to submerged aquatic macrophytes as a tool to evaluate ecological status. The ecological status classification based on the metric hydrophyte cover was "moderate" on the first date and remained "poor" for the rest of the study period (Table 4) due to cyanobacterial mats burying charophyte meadows. For lake type L-T15, an undisturbed-reference condition corresponding to a high ecological status was set by Spanish legislation at a value of $90 \%$ on colonisable substratum (Table 2), whereas the hydrophyte cover was only $4.6 \%$ at the end of the study period. Therefore, macrophyte communities deviated substantially from those normally associated with the surface water body type under undisturbed conditions (normative definition for a "poor" status; WFD, Annexe V).

As for the metric helophyte cover, the continuous perimetral red belt remained constant throughout the study period (100\% cover percentage of helophytes). Therefore, this metric classified the lake as a "high" ecological status (Table 4). When combining the results obtained by the two applied macrophyte metrics and, according to the criterion adopted by the WFD ("the worst status obtained by the applied metrics"), the ecological status was "moderate" in June 2016 and remained "poor" for the rest of the study period (Table 4).

\section{Burial of charophytes by cyanobacterial mats}

The first high-resolution orthoimage of the Alboraj Lake obtained on 23 August 2016 (Fig. 4) clearly captured the extent of the cyanobacterial 


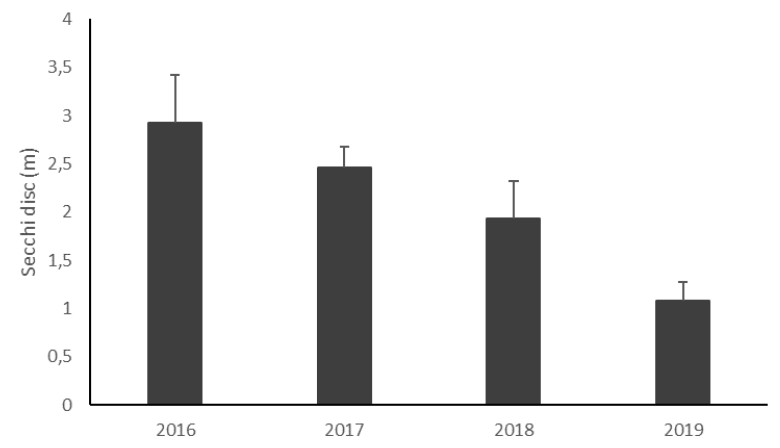

Figure 7. Evolution of the mean and standard errors of the Secchi disc depth from 2016 to 2019 at Lake Alboraj. The burial of charophytes by cyanobacterial mats detected during the study period (July 2016 to July 2017) led the charophyte meadows to collapse and brought about a shift to a turbid alternative state at the lake from 2018 onwards (data taken after the study period). Evolución de los valores medios y desviación típica de la profundidad del disco de Secchi de 2016 a 2019 en la Laguna de Alboraj. El enterramiento de carófitos por tapetes de cianobacterias detectado durante el periodo de estudio (julio 2016 a julio 2017) condujo al colapso de la pradera de carófitos y a un cambio de régimen hacia un estado túrbido alternativo de la laguna a partir de 2018 (datos tomados fuera del periodo de estudio). mats over the charophyte meadow. During the study period, massive cyanobacterial mat growth took place and led to the almost complete burial of charophytes by the end of the study period in July 2017 (Fig. 6). As the cyanobacterial mats cover increased, the charophyte cover decreased, which affected ecological status (Table 4). The final consequence was death and the total elimination of the submerged vegetation in the whole lake from 2018 onwards, followed by the established alternative turbid state (observations after the study period). In the clear water state, the mean Secchi disc depth was around $3 \mathrm{~m}$ (in 2016), but it had gradually decreased to about $1 \mathrm{~m}$ in 2019 after charophytes died (Fig. 7; data from 2018 and 2019 taken after the study period). Therefore, apart from the ecological status evaluation, UAV imagery also proved to be a useful tool for detecting early warning signals of a forthcoming catastrophic shift with important lake conservation management implications.

Lake regime shifts are ecological processes

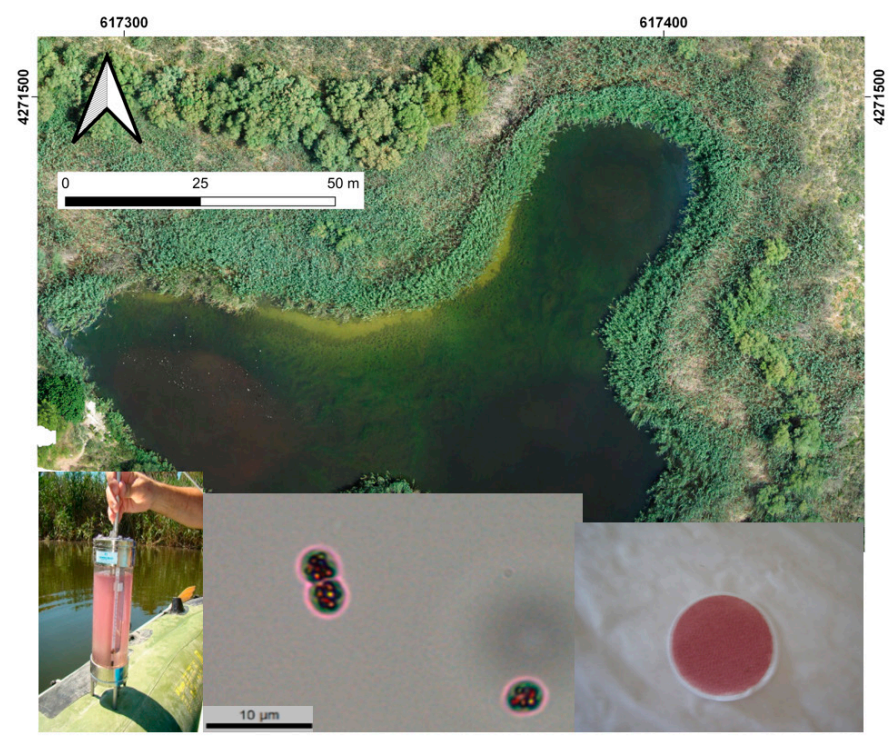

Figure 8. Summer anaerobic purple sulphur bacteria bloom at the bottom of dolines at Lake Alboraj (12/06/2017). Bottom-left, the pink water taken from anoxic hypolimnion (4 m deep) with a Rütner bottle sampler at Lake Alboraj. Bottom centre, the light microscope image of the purple sulphur bacteria (Chromatiaceae) responsible for the pink water colour. Bottom right, a fibreglass filter showing a pink-red colour (12/06/2017). Grid: EPSG: 25830-ETRS89/UTM zone 30N. Bloom estival de bacterias púrpuras del azufre en el fondo de las dolinas en la Laguna de Alboraj (12/06/2017). Abajo a la izquierda, agua rosa tomada del hipolimnion anóxico ( $4 \mathrm{~m}$ de profundidad) con una botella Rütner. Abajo en el centro, imagen de microscopio de bacterias púrpuras del azufre (Chromatiaceae), responsables del color rosa del agua. Abajo a la izquierda, filtro de fibra de vidrio mostrando un color rojo-rosado (12/06/2017). Retícula: EPSG: 25830-ETRS89/UTM zone 30N. 
that have been well-reported in shallow lakes (Scheffer et al., 1993, 2001, 2003). The events and environmental factors that induce these changes have been reported in other studies, and include killing fish, herbicides killing plants, zooplankton killed by pesticides or water level fluctuation (Scheffer et al., 2001). At the studied lake, the shift was promoted by cyanobacterial mat overgrowth, which caused the burial and collapse of charophyte meadows. The end of the clear water charophyte state was followed by a shift to a turbid state from autumn 2018 onwards. The early warning signal (i.e. burial of charophytes by cyanobacterial mats) detected by UAV imagery in the clear water state preluded the undesirable dominance shift from the clear (dominated by submerged macrophytes) to the turbid state (dominated by phytoplankton) observed in later study period years.

The cause of cyanobacterial overgrowth could have been promoted by a eutrophication process that commenced in lake sediments, which accumulate high organic matter content from phytoplankton and macrophytes. Sediment organic matter decomposition may lead to the release of nutrients (mainly phosphorous) to the water column (Blomqvist et al., 2004, Conley et al., 2009) which, in turn, could cause lake eutrophication and cyanobacterial overgrowth (Westman et al., 2003, Havens et al., 2001). Released nutrients could also have been facilitated by bioturbation of sediments by carps (Cyprinus carpio) (Moreno et al., 2018).

\section{Stratification processes detected by UAV imagery}

On some dates, images showed a reddish colour at the bottom of dolines (Fig 8). The water column depth profile obtained in June 2017 revealed physicochemical and biological stratification (Table 5). An oxycline located between 2.5 and $3.5 \mathrm{~m}$ split an aerobic epilimnion from a colder and denser anaerobic hypolimnion. The water samples taken immediately below the oxycline at a depth of $4 \mathrm{~m}$ in the SE doline displayed a pink colour that corresponded to the reddish colour recorded in the UAV orthoimage (Fig. 8). The pink water presented a strong smell of hydrogen sulphide, and the presence of purple sulphur bacteria was

Table 5. Summer physicochemical and biological stratification of the water column in the SE doline of Lake Alboraj (12/06/2017). Estratificación fisico-química y biológica estival de la columna de agua en la dolina SE de la Laguna de Alboraj (12/06/2017).

\begin{tabular}{cccccccc}
\hline Depth & $\begin{array}{c}\mathrm{O}_{2} \\
(\mathrm{mg} / \mathrm{l})\end{array}$ & $\begin{array}{c}\mathrm{O}_{2} \\
(\%)\end{array}$ & $\begin{array}{c}\text { Temperature } \\
\left({ }^{\circ} \mathrm{C}\right)\end{array}$ & $\begin{array}{c}\text { Conductivity } \\
(\mathrm{mS} / \mathrm{cm})\end{array}$ & $\begin{array}{c}\mathrm{Chl} a \\
\left(\mathrm{mg} / \mathrm{m}^{3}\right)\end{array}$ & $\begin{array}{c}\mathrm{Bchl} a \\
\left(\mathrm{mg} / \mathrm{m}^{3}\right)\end{array}$ \\
\hline 0.5 & 2.7 & 34.8 & 24.6 & 9.9 & 7.36 & - & - \\
1.0 & 2.6 & 33.2 & 24.5 & 9.9 & 7.37 & 3.2 & 2.4 \\
1.5 & 2.5 & 31.5 & 24.4 & 9.9 & 7.38 & - & - \\
2.0 & 2.5 & 31.6 & 24.3 & 9.9 & 7.44 & 3.7 & 1.7 \\
2.5 & 2.1 & 27.2 & 24.3 & 9.9 & 7.42 & - & - \\
3.0 & 1.6 & 20 & 24.2 & 10.0 & 7.44 & 5.4 & 6.5 \\
3.5 & 0.3 & 4.3 & 24.1 & 9.9 & 7.36 & - & - \\
4.0 & 0.1 & 1.3 & 21.4 & 10.6 & 7.01 & 28.7 & 482.6 \\
4.5 & 0.1 & 1.1 & 18.3 & 11.2 & 7.03 & - & - \\
\hline
\end{tabular}


confirmed in the laboratory by several ways. The light microscopy (Fig. 7) of live samples revealed the presence of abundant motile bacteria with intracellular sulphur globules and without gas vesicles, which included the typical features of the family Chromatiaceae; i.e. purple sulphur bacteria (Trüper \& Pfennig, 1981, Häusler, 1982, Pfennig and Trüper, 1989, Imhoff, 2005). The most abundant cells were ovoid to spherical shaped (size: 3-4 $\mu \mathrm{m}$ wide and 3-6 $\mu \mathrm{m}$ long), and often diplococcus-shaped, before cell division, motile by flagella, occurring singly or in pairs, with intracellular highly refractile sulphur globules, mainly peripheral (Fig. 7). These morphological features might correspond to some species of the genus Thiocystis according to Bergey's Manual of Systematic Bacteriology (Imhoff, 2005), but this study included no genetical or physiological analyses. A high bacteriochlorophyll $a$ concentration $\left(482.6 \mathrm{mg} / \mathrm{m}^{3}\right)$ in the 4 metre-deep water sample with the typical absorption peak at $772 \mathrm{~nm}$ in acetone extract (Tachahasi \& Ichimura, 1970) also confirmed the purple sulphur bacteria bloom (Table 5). A similar bacteriochlorophyll $a$ concentration corresponding to purple sulphur bacterial layers has been recorded in other studies from Spanish karstic sulphated lakes (Guerrero et al., 1985, Vicente et al., 1991).

The presence of sulphate is important because it usually results in sulphate reduction by bacteria (Desulfovibrio-like) and, consequently, in sulphide production at lower lake layers (Guerrero \& Pedrós-Alió, 1992). This sulphide provides phototrophic sulphur bacteria with reducing power and allows them to develop if enough light reaches anaerobic waters (Miracle et al., 1992). In this context, several karstic sulphated lakes in which purple sulphur bacteria were present have been studied in Spain; for example, small lakes in the Lake Banyoles complex (NE Spain, Girona) or Lake Arcas-2 (SE Spain, Cuenca). Their sulphate concentration was around 1000-2000 mg/l with conductivity values ca. $2 \mathrm{mS} / \mathrm{cm}$ (Miracle et al., 1992), while Lake Alboraj had a higher sulphate concentration, at around $7000 \mathrm{mg} / \mathrm{l}$, and a higher range of conductivity values of $9-12 \mathrm{mS} / \mathrm{cm}$ (Table 1; Table 5). This high sulphate concentration favours the presence of phototrophic sulphur bacteria, which usually concentrate below the oxy- gen-sulphide interface or the redoxycline (Vicente et al., 1991, Guerrero \& Pedrós-Alió, 1992).

High sulphate concentration and reducing conditions on the anaerobic hypolimnion are key factors for $\mathrm{H}_{2} \mathrm{~S}$ availability and, therefore, purple sulphur bacteria development (Vicente et al., 1991, Guerrero \& Pedrós-Alió, 1992). These conditions are well reflected by the oxygen gradient recorded in the depth profile in June 2017, but also by the $\mathrm{pH}$ gradient, which lowered from 7.36 on the epilimnion to 7.03 on the hypolimnion (Table 5). The lowering $\mathrm{pH}$ on the hypolimnion could mainly be due to the accumulation of $\mathrm{H}_{2} \mathrm{~S}, \mathrm{CO}_{2}$ and organic acids (Camacho, 1997). Redox potential Eh was not measured at that time, but the later measurements taken at the Lake Alboraj beyond the study period under the same stratification conditions (June 2019; unpublished data) ranged from $+70.7 \mathrm{mV}$ on the epilimnion to $-375 \mathrm{mV}$ in hypolimnetic waters. These are optimal reducing conditions for purple sulphur bacteria. Likewise, several $\mathrm{H}_{2} \mathrm{~S}$ measurements on the hy-

Table 6. Depth profile of dissolved oxygen $(\mathrm{mg} / \mathrm{l})$ in the winter stratification. White colloidal layers were detected on the oxycline (metalimnion) at $1.5 \mathrm{~m}$ and $2.5 \mathrm{~m}$ on $26 / 01 / 2017$ and 07/03/2017, respectively. Perfil de oxígeno disuelto ( $\mathrm{mg} / \mathrm{l}$ ) en la estratificación invernal. Se detectaron capas blancas coloidales en la oxiclina (metalimnion) a 1.5 y $2.5 \mathrm{~m}$, el 26/01/2017 y el 07/03/2017 respectivamente..

\begin{tabular}{ccc}
\hline & \multicolumn{2}{c}{ Dissolved oxygen $(\mathrm{mg} / \mathrm{l})$} \\
\hline Depth & $26 / 01 / 2017$ & $07 / 03 / 2017$ \\
\hline 0.5 & 12.97 & 9.18 \\
1.0 & 13.14 & 9.17 \\
1.5 & 0.35 & 7.19 \\
2.0 & 0.18 & 2.07 \\
2.5 & 0.11 & 3.79 \\
3.0 & 0.11 & 0.12 \\
3.5 & 0.1 & 0.09 \\
4.0 & 0.1 & 0.08 \\
4.5 & 0.08 & 0.09 \\
\hline
\end{tabular}


polimnion were taken beyond the study period (July 2018) under similar stratification conditions using a field sulphide kit (Häch), which gave concentration values of $50-60 \mathrm{mg} / \mathrm{l} \mathrm{H}_{2} \mathrm{~S}$. These values are in accordance with those obtained in other Spanish karstic sulphated lakes where purple sulphur bacteria abound (Miracle et al., 1992).

Another stratification process, related to the anaerobic hypolimnion, was detected by UAV imagery and captured in winter (February 2017). The lake orthoimage showed a white colour in the centre of dolines where stratification occurred (Fig. 9). The water samples taken from the boat in the SE doline indicated a white colloidal layer that was about $0.5 \mathrm{~m}$ thick exactly on the oxycline (metalimnion), which moved between 1.5-2.5 m in winter (Table 6). No analyses were run in this study to identify this layer's chemical composition. However, the hypothesis of the white colour possibly corresponding to the concentration of elemental sulphur and other sulphur products (thiosulphates, polysulphides) produced by sulphide oxidation can be argued (e.g. Verhoeven, 2009, Duranceau et al., 2010), mainly the oxidation of $\mathrm{H}_{2} \mathrm{~S}$ released from sediment. As in other Spanish karstic sulphated lakes, sulphide oxidation leads to the accumulation of colloidal elemental sulphur (Guerrero et al., 1980, Vicente et al., 1991). In marine environments (with a much lower sulphate concentration than that in the studied lake), extensive areas affected by this phenomenon have been detected by satellite images and are known as "white-water" events (Ferdelman et al., 1999, Weeks et al., 2002, Brüchert et al., 2006, Ohde et al., 2007). Further research is necessary to corroborate this hypothesis as to the origin of this metalimnetic white layer in the studied lake.

Another aspect to bear in mind from the management point of view is that sulphide $\left(\mathrm{H}_{2} \mathrm{~S}\right)$ is a well-known lethal toxic gas for many organisms like fish (Bagarinao, 1992). Indeed, former massive fish deaths have been previously reported at Lake Alboraj (Moreno et al., 2018). Therefore, the early detection of stratification processes (i.e.

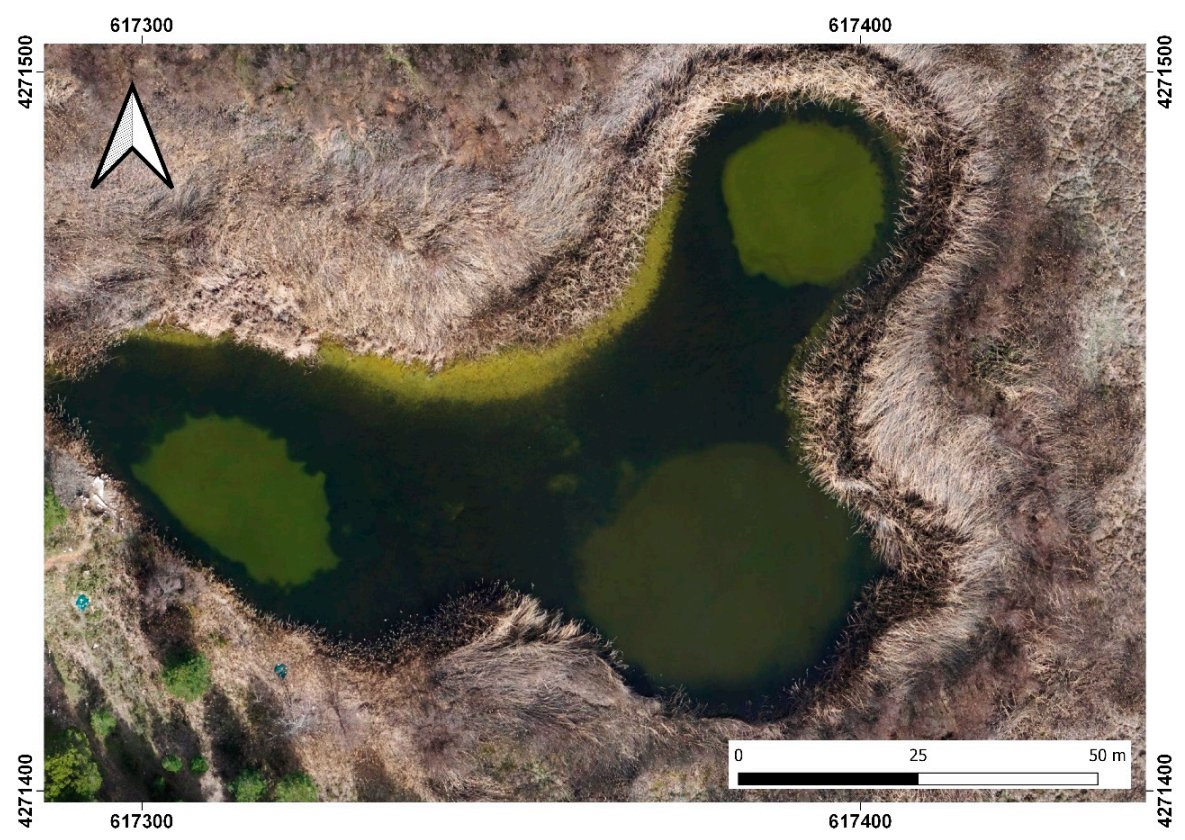

Figure 9. Winter image of Lake Alboraj obtained by UAV (22/02/2017). The three dolines show a light-green colour due to the presence of a white colloidal layer located on the oxycline (see Table 6). Grid: EPSG: 25830-ETRS89/UTM zone 30N. Imagen invernal de la Laguna de Alboraj obtenida con drones (22/02/2017). Las tres dolinas muestran un color verde claro debido a la presencia de una capa blanca coloidal localizada en la oxiclina (ver Tabla 6). Retícula: EPSG: 25830-ETRS89/UTM zone 30N. 
deep pink and white layers) by UAV imagery could be used as an early warning tool to make risk assessments of emergent anoxic conditions.

\section{Advantages of applying UAV}

In this study, eight high-resolution UAV imagery sessions equipped with an RGB camera (GSD of $2.5 \mathrm{~cm}$ ) allowed some ecological condition aspects to be characterised in a small lake covering 0.5 ha. The temporal evolution of macrophyte beds for several months and other biological processes were successfully detected by the proposed methodology. Other authors have successfully monitored and analysed aquatic vegetation using a GSD of $2.5 \mathrm{~cm}$ for RGB images with similar results to those herein reported for the method's validity (Kageyama et al., 2018, Chabot et al., 2018). High-resolution imagery using the LAIC software classification and ANN allowed the whole lake to be analysed and can be applied to bigger lakes, although the coverage abilities and temporal requirements for large-scale data collection, costs or data storage abilities should be considered for big lakes. Although LAIC software was originally applied to agricultural fields, this software is also suited to aquatic environments: for example, Rivas et al. (2015) obtained high accuracy (more than $81 \%$ ) performing high resolution imagery classification by using LAIC software in rivers.

The quantification of biological quality elements (abundance, cover) is a key issue for evaluating the ecological status of water bodies according to the WFD. The cover percentage of submerged macrophytes, specifically the extent of charophyte meadows, was efficiently quantified in this study from the orthoimages obtained by UAV imagery. Field macrophyte surveys include traditional sampling methods, such as transects, plots, the use of bathyscopes, Ekman grabs, or subaquatic surveys, which require investing many sampling efforts (Hunter et al., 2010). In Spanish lakes, national protocols require 10 (for small lakes $<50 \mathrm{ha}$ ) or 20 (for lakes $>50 \mathrm{ha}$ ) transects to be performed using a boat. The abundance of hydrophytes in each transect is an estimated value obtained by either exploring with bathyscopes or extracting a certain number of samples with grabs or rakes at the intervals (plots) within each transect. Then the total macrophyte cover in the whole lake is inferred by gathering the transect/ plot data abundances obtained discontinuously in space. Therefore, the whole macrophyte cover at the lake is often difficult to quantify accurately by traditional methods and is even more complicated if we consider the spatial heterogeneity and aggregation patterns of macrophyte communities (Hunter et al., 2010). However, high-resolution UAV imagery can provide almost real macrophyte cover measures. UAV imagery can substitute field transect works by being a very efficient, and potentially more accurate, method to measure the macrophyte cover that is not affected by the spatial arrangement of macrophyte patches. Thus, many authors agree about the effectiveness of UAV methods for mapping and quantifying submerged and emergent aquatic vegetation (Hunter et al., 2010, Venturi et al., 2016, Rhee et al., 2017, Chabot et al., 2018, Kageyama et al., 2018, Meneses et al., 2018).

With the proposed methodology, a high-resolution orthoimage (GSD $2.5 \mathrm{~cm}$ ) can be obtained from flight planning the final product in almost real time. In this study, the flight duration to collect remote sensing information lasted no longer than 30 minutes, which is a very short time compared to field macrophyte surveys, which currently take at least 3 hours to perform transects and to collect macrophyte abundance data for the ecological status assessment of Spanish lakes. Additionally, the short time required by UAV flights avoids some issues related to sun tilt or other changing weather conditions and does not, therefore, affect the quality of the results (Rivas et al., 2016). Moreover, once the field validation has been performed in a lake, the temporal evolution of the macrophyte community cover and ecological processes in the lake are affordable with this time-effective method, which can become a useful tool for risk assessments and environmental management.

UAV methods followed to quantify macrophyte cover are apparently less invasive than traditional macrophyte surveys based on transect/ plot methods, which can be an advantage to be considered for preserving lake integrity. Flight operations are performed from the lake shore and the short duration of drone flights barely im- 
pacts the aquatic environment, except for reduced fieldwork validation. In contrast, traditional surveys performed to quantify aquatic vegetation (transects/plots) often take several hours and can cause greater lake ecosystem perturbations (use of grabs and rakes, waterfowl disturbances, etc.) than UAV flights. Moreover, the small-sized UAV used in this study did not seem to bother the waterfowl in the studied lake (a small population of ducks and coots).

Finally, successful detection of ecological events and stratification processes by UAV imagery, which were not identified from a ground view, is a relevant result of this study. The deep stratification processes detected by the UAV RGB images were completely ignored by a ground view. For example, deep sulphur bacteria blooms at the bottom of dolines ( $4 \mathrm{~m}$ deep) were not noticed from a boat, and the same occurred with the formation of white colloidal layers at a depth of 2 $\mathrm{m}$. Likewise, the burial of charophytes by cyanobacterial mats was not detected until the RGB images had been processed. These results emphasise the advantages of using UAV imagery for ecological monitoring purposes.

\section{Limitations of applying UAV}

The proposed UAV-based method has some limitations that must be considered in ecological assessments. The following limitations are outlined: 1) consider the restrictions of national regulations on drone use; 2) weather conditions affect geomatic product quality; 3) when assessing the temporal evolution of a water body, intrinsic aspects might change between flights and affect the end result; 4) other different constraints may come into play, such as the presence of obstacles or barrier elements, waves disturbing the water surface, administrative limitations in preserved areas, etc.

National regulations must be checked and met in the flight planning phase. Areas over which it is forbidden to fly drones (urban zones, infrastructure, roads, security zones, airports, military installations, etc.) should not lie near the studied water body. Height flight is also limited and differs between countries. Similarly, flight distance might be limited by regulations. Regarding Natural Protected Areas (including waterfowl breeding areas, sensitive wetlands for waterfowls, ZEPAs), drones are not generally allowed. It is necessary to request authorisation for scientific proposes from the organisation responsible for managing preserved areas.

The main limitation of the method followed in the present study was wind velocity. Wind tolerance depends on equipment, specifically its size and weight. With the equipment herein used (Microdrones md4-1000, $1.2 \mathrm{~kg}$ ), flights were performed at a wind velocity lower than $2 \mathrm{~m} / \mathrm{s}$. A higher wind velocity can produce blurry images. During the study period, flights were impracticable on $12.3 \%$ of the days due to adverse weather conditions, such as high wind velocity. Cloudiness and lighting also affect the results. Performing flights at noon is recommendable, at around 12:00 h solar time (Ortega-Terol et al., 2017).

Water clarity or turbidity is the main constraint related to the water body condition that affects the maximum depth visible on the UAV images. Generally, with RGB cameras and under normal lighting conditions and clear waters, it is possible to classify the submerged vegetation of lakes up to a depth of $2.5 \mathrm{~m}$ (Kageyama et al., 2018, Tóth, 2018), but changes in turbidity can affect the maximum depth resolution. In the studied lake, features at a depth of $4 \mathrm{~m}$ were detected under clear water conditions, which makes this methodology very useful for detecting lake stratification processes and for mapping deep macrophyte communities.

Finally, another limitation was water surface stabilisation due to either the formation of waves by wind or displacements of water birds as waves make the visibility of lake bottoms difficult. Occasionally, some images were affected by coots moving over the water surface during flight (see Fig. 4a, the bright white cloud at the top left of the image), although short flight durations can avoid this inconvenience.

\section{CONCLUSIONS}

The following results obtained with this study are emphasised:

1) UAV imagery can be used to map submerged lake vegetation. The macrophyte cover (including hydrophytes and helophytes) can be 
addressed by this methodology for ecological status assessments in the WFD context. High-resolution UAV imagery can provide almost real macrophyte cover measures, unlike the estimations inferred by traditional macrophyte surveys based on transects/plots.

2) UAV imagery detected ecological processes of interest for lake management purposes: decaying charophyte meadows by epiphytic cyanobacterial proliferation; deep purple sulphur bacteria blooms; and other stratification processes (metalimnetic white colloidal layers).

3) The ecological processes detected by UAV imagery (burial of charophytes, stratification features) were neglected at the ground view from a boat, and they were not detected until the RGB images were processed. These results emphasise the usefulness of high-resolution UAV imagery for ecological monitoring purposes.

4) The proposed methodology for quantifying the whole lake macrophyte cover is less time-consuming than traditional methods based on fieldwork by transects/plots.

\section{ACKNOWLEDGMENTS}

The Instituto de Estudios Albacetenses funded part of this study. The authors thank Miguel Navarro for his essential support in the limnological surveys and Ana Isabel López Archilla (Universidad Autónoma de Madrid) for identifying cyanobateria.

\section{REFERENCES}

Agisoft LLC (2011). Agisoft PhotoScan User Manual.

APHA (1985). Standard methods for the examination of water and wastewater. American Public Health Association, Washington.

Bagarinao, T. (1992). Sulphide as an environmental factor and toxicant: tolerance and adaptatins in aquatic organisms. AquaticToxicology, 24, 21-62. DOI: 10.1016/0166-445X(92)90015-F

Ballesteros R, Ortega, J. F., Hernández-López, D., del Campo A. \& Moreno, M. A. (2018). Combined use of agro-climatic and very high-resolution remote sensing information for crop monitoring. International Journal of Applied
Earth Observation and Geoinformation, 72, 66-75. DOI: 10.1016/j.jag.2018.05.019

Blomqvist, S., Gunnars, A. \& Elmgren, R. (2004). Why the limiting nutrient differs between temperate coastal seas and freshwater lakes: A matter of salt. Limnology and Oceanography, 49(6), 2236-2241.

Brüchert, V. \& Arne, D. (2006). Biogeochemical and physical control on shelf anoxia and water column hydrogen sulphide. In: Neretin. L. N. (ed.). Past and Present Water Column Anoxia. (pp 161-193). Springer, Dordrecht, Netherlands.

Camacho, A. 1997. Ecología de los microorganismos fotosintéticos en las aguas microaerófilas y anóxicas de la Laguna de Arcas. PhD Thesis. University of Valencia. Spain.

Camacho, A., Borja, C., Valero-Garcés, B., Sahuquillo, M., Cirujano, S., Soria, J. M., Rico, E., De La Hera, A., Santamans, A. C., García De Domingo, A., Chicote, A. \& Gosálvez, R. U. (2009). 3190 Lagos y lagunas kársticas sobre yesos. In: VV.AA. Bases ecológicas preliminares para la conservación de los tipos de hábitat de interés comunitario en España. (pp. 37). Ministerio de Medio Ambiente, y Medio Rural y Marino, Madrid, Spain.

Chabot, D., Dillon, C., Shemrock, A., Weissflog, N. \& Sager, E. P. S. (2018). An Object-Based Image Analysis Workflow for Monitoring Shallow-Water Aquatic Vegetation in Multispectral Drone Imagery. International Journal of Geo-Information, 7, 294. DOI: 10.3390/ ijgi7080294

CHS, 2016. Trabajos de medida de caudales en manantiales y niveles hidrométricos y piezométricos en humedales de la cuenca del Segura. Confederación Hidrográfica del Segura. Oficina de Planificación Hidrológica. Murcia. Spain.

Colomina, I. \& Molina, P. (2014) Unmanned aerial systems for photogrammetry and remote sensing: A review. ISPRS Journal of Photogrammetry and Remote Sensing, 92, 79-97. DOI: 10.1016/j.isprsjprs.2014.02.013

Conley, D. J., Paerl, H. W., Howarth, R. W., Boesch, D. F., Seitzinger, S. P., Havens, K. E., Lancelot, C. \& Likens G. E. (2009). Controlling Eutrophication: Nitrogen and Phos- 
phorus. Science, 323 (5917), 1014-1015. DOI: $10.1126 /$ science. 1167755

Córcoles, J. I., Ortega, J. F., Hernández, D, \& Moreno, M. A. (2013). Estimation of leaf area index in onion (Allium cepa L.) using an unmanned aerial vehicle. Biosystems Engineering, 115, 31-42. DOI: 10.1016/j.biosystemseng.2013. 02.002

DeBell, L., Anderson, K., Brazier, R. E., King, N. \& Jones, L. (2016). Water resources management at catchment scales using lightweight UAVs: current capabilities and future perspectives. Journal of Unmanned Vehicle Systems, 4, 7-30. DOI: 10.1139/juvs-2015-0026

Doña, C., Sanchez, J. M., Caselles, V., Domínguez, J. A. \& Camacho, A. (2014). Empirical relationships for monitoring water quality of lakes and reservoirs through multispectral images. IEEE Journal of Selected Topics in Applied Earth Observations and Remote Sensing, 7, 1632-1641. DOI: 10.1109/ JSTARS.2014.2301295

Duranceau, S. J., Trupiano, V. M., Lowenstine, M., Whidden, S. \& Hopp J (2010). Innovative Hydrogen Sulfide Treatment Methods: Moving Beyond Packed Tower Aeration. Florida Water Resources Journal, 7, 4-14.

ERGNSS (2008). Spanish national GNSS reference stations network. Resource document.

European Communities (2003). River and lakes Typology, reference conditions and classification systems. Common Implementation Strategy for The Water Framework Directive (2000/60/EC). Guidance Document No 10.

Ferdelman, T., Fossing, H., Neumann, K. \& Schulz, D. (1999). Sulfate reduction in surface sediments of the southeast Atlantic continental margin between 158389S and 278579S (Angola and Namibia). Limnology and Oceanography, 44(3), 650-661. DOI: 10.4319/1o.1999.44. 3.0650

Flynn, K. F. \& Chapra, S. C. (2014). Remote sensing of submerged aquatic vegetation in a shallow Non-Turbid river using an unmanned aerial vehicle. Remote Sensing, 6, 1281512836. DOI: $10.3390 /$ rs61212815

Ghazal, M., Khalil, Y. A. \& Hajjdiab, H. (2015). UAV-based remote sensing for vegetation cover estimation using NDVI imagery and level sets method. 15th IEEE International Symposium on Signal Processing and Information Technology (ISSPIT 2015). 7-10 December, Abu Dhabi, UAE.

Guerrero, R., Montesinos, E., Esteve, I. \& Abella, C. (1980). Physiological Adaptation and Growth of Purple and Green Sulfur Bacteria in a Meromictic Lake (Vila) as Compared to a Holomictic Lake (Siso). Developments in Hydrobiology, 3, 161-171.

Guerrero, R. \& Pedrós-Alió, C. (1992). The microbial component in spanish aquatic ecosystems. Limnetica, 8, 175-184.

Guerrero, R., Montesinos, E., Pedrós-Alió, C., Esteve, I., Mas, J.. Van Gemerden, H., Hofman, P. A. \& Baker, J. F. (1985). Phototrophic sulfur bacteria in two spanish lakes: vertical distribution and limiting factors. Limnology and Oceanography, 30, 919-931. DOI: 10.4319/1o. 1985.30.5.0919

Havens, K. E., Fukushima, T., Xie, P., Iwakuma, T., James, R .T., Takamura, N., Hanazato, T. \& Yamamoto, T. (2001). Nutrient dynamics and the eutrophication of shallow lakes Kasumigaura (Japan), Donghu (PR China), and Okeechobee (USA). Environmental Pollution, 111(2), 263-72. DOI: 10.1016/s0269-7491(00) 00074-9

Häusler, J. (1982). Süßwasserflora von Mitteleuropa, Bd. 20: Schizomycetes. Gustav Fischer Verlag, Stuttgart.

Hernández-López, D., Felipe-Garcia, B., González-Aguilera, D. \& Arias-Pérez, B. (2013). An automatic approach to UAV flight planning and control for photogrammetric application. Photogrammetric Engineering \& Remote Sensing, 79, 87-98. DOI: 10.14358/ PERS.79.1.87

Hu, C., Feng, L., Hardy, R. F. \& Hochberg, E. J. (2015). Spectral and spatial requirements of remote measurements of pelagic Sargassum macroalgae. Remote Sensing of Environment, 167, 229-245. DOI: 10.1016/j.rse.2015.05.022 Hunter, P. D., Gilvear, D. J., Tyler, A. N., Willby, N. J. \& Kelly, A. (2010). Mapping macrophytic vegetation in shallow lakes using the compact airborne spectrographic imager (CASI). Aquatic Conservation, 20, 717-727. DOI: 10. 1002/aqc. 1144 
Husson, E, Hager O. \& Ecke. F. (2013) Unmanned aircraft systems help to map aquatic vegetation. Applied Vegetation Science, 17(3), 567-577. DOI: 10.1111/avsc. 12072

IGME (2009). Identificación y caracterización de la interrelación que se presenta entre aguas subterráneas, cursos fluviales, descargas por manantiales, zonas húmedas y otros ecosistemas naturales de especial interés hídrico. Masa de agua subterránea 071.005 TobarraTedera-Pinilla. Instituto Geológico y Minero de España. Ministerio de Medio Ambiente, Medio Rural y Marino. Madrid. Spain.

Imhoff, J. F. (2005). Family I. Chromatiaceae. In: Brenner, D. J., Krieg N. R., Staley J. R. \& Garrity, G. (eds.). Bergey's Manual of Systematic Bacteriology. Second Edition. Volume Two. The Proteobacteria. Part B. The Gammaproteobacteria. (pp. 3-40). Springer. Dordrecht, Netherlands.

JCCM (2015). Plan de Gestión de Saladares de Cordovilla y Agramón y Laguna de Alboraj, ES4210011 (Albacete). Junta de Comunidades de Castilla-La Mancha.

Jeffrey, S. W. \& Humphrey, G. (1975). New spectrophotometric equations for determining chlorophyll $a, b, c_{1}$ and $c_{2}$ in higher plants, algae and natural phytoplankton. Biochemie und Physiologie der Pflanzen, 167, 191-194.

Jones, K. H. \& Gross, J. (2014). Reducing size, weight, and power (SWaP) of perception systems in small autonomous aerial systems. In: Proceedings of the 14th AIAA Aviation Technology, Integration, and Operations Conference. 16-20 June 2014, Atlanta, Georgia, USA.

Kageyama, Y., Wakatabe, K., Ishikawa, M., Kobori, B. \& Nagamoto, D. (2018). Application of Fuzzy Regression Analysis and Fuzzy C-Means Technique Using UAV Data to Understand Water Quality in the Miharu Dam Reservoir, Japan. IEEJ Transactions on Electrical and Electronic Engineering, 13, 18311832. DOI: $10.1002 /$ tee. 22745

Koparan, C. (2016). Unmaned Aerial Vehicle (UAV)-Assited Water Sampling. PhD. Theses. Clemson University, South Carolina, USA.

Krupska, J., Pełechaty, M., Pukacz, A. \& Ossowski, P. (2012). Effects of grass carp introduction on macrophyte communities in a shal- low lake. Oceanological and Hydrobiological Studies, 41, 35-40. DOI: 10.2478/s13545-0120004-4

Kubiak, K. A., Kotlarz, J. \& Mazur, A. M. (2016). Monitoring Cyanobacteria Blooms in Freshwater Lakes using Remote Sensing Methods. Polish Journal of Environmental Studies, 25, 27-35. DOI: 10.15244/pjoes/60175

Kudela, R. M., Palacios, S. L., Austerberry, D. C. \& Accorsi, E. K. (2015). Application of hyperspectral remote sensing to cyanobacterial blooms in inland waters. Remote Sensing of Environment, 167, 196-205. DOI: 10.1016/j.rse. 2015.01.025

MAGRAMA (Ministerio de Agricultura, Alimentación y Medio Ambiente) (2013a). Protocolo de laboratorio y cálculo de métricas de otro tipo de flora acuática (Macrófitos) en lagos. Código: OFALAM-2013.

MAGRAMA (Ministerio de Agricultura, Alimentación y Medio Ambiente) (2013b). Protocolo de muestreo de otro tipo de flora acuática (macrófitos) en lagos. Código M-LOFM-2013.

MAGRAMA (Ministerio de Agricultura, Alimentación y Medio Ambiente) (2015). Real Decreto 817/2015, de 11 de septiembre, por el que se establecen los criterios de seguimiento y evaluación del estado de las aguas superficiales y las normas de calidad ambiental. BOE-A-2015-9806.

Meneses, N. C., Baier, S., Reidelstürz, P., Geist, J. \& Schneider, T. (2018). Modelling heights of sparse aquatic reed (Phragmites australis) using Structure from Motion point clouds derived from Rotary-and Fixed-Wing Unmanned Aerial Vehicle (UAV) data. Limnologica, 72, 10-21. DOI: 10.1016/j.limno.2018.07.001

Miracle M. R., Vicente E. \& Pedrós-Alió C. (1992). Biological studies of Spanish meromictic and stratified karstic lakes. Limnetica, 8, 59-77.

Moreno, J. L., Monteagudo. L., Florin, M., Chicote, A., Ortega, J. F., Ballesteros, R., Moreno, M. A. \& De Las Heras, J. (2018). Evolución histórica y reciente de la de Laguna de Alboraj (Tobarra, Albacete): bases para su estudio. III Jornadas sobre el Medio Natural Albacetense, pp. 402-41. Instituto de Estudios Albacetens- 
es. Albacete. Spain.

Nex, F. \& Remondino, F. (2014). UAV for 3D mapping applications: a review. Applied Geomatics, 6(1), 1-15. DOI: 10.1007/s12518-0130120-x

Ohde, T., Siegel, H., Reißmann, J. \& Gerth, M. (2007). Identification and investigation of sulphur plumes along the Namibian coast using the MERIS sensor. Continental ShelfResearch, 27, 744-756. DOI: 10.1016/j.csr.2006.11.016

Ortega-Terol, D., Hernandez-Lopez, D., Ballesteros, R. \& Gonzalez-Aguilera, D. (2017). Automatic hotspot and sun glint detection in UAV multispectral images. Sensors, 17, 2352. DOI: $10.3390 / \mathrm{s} 17102352$

Pfennig, N. \& Trüper, H. G. (1989). Family I. Chromatiaceae. In: Staley, Bryant, Pfennig and Holt (Eds.). Bergey's Manual of Systematic Bacteriology. First Edition. Volume 3. The Williams Sc Wilkins Co., Baltimore. pp. 1657-1655.

Rhee, D. S., Kim, Y. D., Kang, B. \& Kim, D. (2017). Applications of Unmanned Aerial Vehicles in Fluvial Remote Sensing: An Overview of Recent Achievements. KSCE Journal of Civil Engineering, 22, 588-602. DOI: 10.1007/s12205-017-1862-5

Rivas, M., Ballesteros, R., Kriechbaumer, T. \& Veal, A. (2015). Automated identification of river hydromorphological features using UAV high resolution aerial imagery. Sensors, 15, 27969-27989. DOI: 10.3390/s151127969

Rivas, M., Ballesteros, R., Wright, R. \& Bellamy, P. (2016). Quantifying the effect of aerial imagery resolution in automated hydromorphological river characterisation. Remote Sensing, 8, 650. DOI: 10.3390/rs808065

Rivas, M., Ballesteros, R., Ortega, J. F., Leinster, P. \& Wright, R. (2017). Towards a transferable UAV-based framework for river hydromorphological characterization. Sensors, 17, 2210. DOI: $10.3390 / \mathrm{s} 17102210$

Rodríguez-Pascua, M. A., Pérez-López, R., Garduño-Monroy, V. H., Giner-Robles, J. L., Silva, P. G., Perucha-Atienza, M. A., Hernández-Madrigal, V. M. \& Bischoff, J. (2012). Paleoseismic and geomorphologic evidence of recent tectonic activity of the Pozohondo Fault (Betic Cordillera, SE Spain). Journal of Iberi- an Geology, 38 (1), 239-251. DOI: 10.5209/ rev_JIGE.2012.v38.n1.39216

Scheffer, M. \& Carpenter, S. R. (2003). Catastrophic regime shifts in ecosystems, linking theory to observation. Trends in Ecology and Evolution, 18, 648-656. DOI: 10.1016/j. tree.2003.09.002

Scheffer, M. \& Jeppesen, E. (2007). Regime shifts in shallow lakes. Ecosystems, 10, 1-3.

Scheffer, M., Hosper, S. H., Meijer, M-L., Moss, B. \& Jeppesen, E. (1993). Alternative equilibria in shallow lakes. Trends in Ecology and Evolution, 8, 275-279. DOI: 10.1016/01695347(93)90254-M

Scheffer, M., Carpenter, S., Foley, J. A., Folke, C. \& Walker, B. (2001). Catastrophic shifts in ecosystems. Nature, 413, 591-596. DOI: 10.1007/s10021-006-9002-y

Sòria-Perpinyà, X, Urrego, P., Pereira-Sandoval, Marcela, Ruiz-Verdú, A., Peña, R.,. Soria, J. M, Delegido, J., Vicente, E. \& Moreno, J. (2019). Monitoring the ecological state of a hypertrophic lake (Albufera of València, Spain) using multitemporal Sentinel-2 images. Limnetica, 38(1), 457-469. DOI: 10.23818/ limn.38.26

Takahashi, M. \& Ichimura, S. (1970). Photosynthetic properties and growth of photosynthetic sulfur bacteria in lakes. Limnology and Oceanography, 15, 929-944. DOI: 10.4319/ lo.1970.15.6.0929

Tóth, V. R. (2018). Monitoring spatial variability and temporal dynamics of Phragmites using Unmanned Aerial Vehicles. Frontiers in Plant Science, 9, 728. DOI: 10.3389/fpls. 2018.00728

Trüper H. G. \& Pfennig, N. (1981). Characterization and Identification of the Anoxygenic Phototrophic Bacteria. Chapter 18. In: Mortimer P. S., Stolp, H., Trüper, H. G., Balows, A. \&. Schlegel H. G. (eds.), The Prokaryotes. A Handbook on Habitats, Isolation, and Identification of Bacteria. (pp. 299-312). Springer-Verlag, Berlin, Heidelberg. DOI: 10. 1007/978-3-662-13187-9_18

Valiente, E., Miracle, M. R., Armengol, J., Camacho, A. \& Roca, J. R. (1997). Estudio limnológico de 28 humedales de Castilla-La Mancha como base para la elaboración del 
Plan de Ordenación de Recursos Naturales. Universidad de Valencia y Junta de Comunidades de Castilla-La Mancha. Report. DOI: 10.13140/RG.2.1.4235.2164

Van den Berg, M. S., Coops, H., Meijer, M. L., Scheffer, M. \& Simons, J. (1998). Clear Water Associated with a Dense Chara Vegetation in the Shallow and Turbid Lake Veluwemeer, The Netherlands. In, Jeppesen, E., Søndergaard, M., Søndergaard, M., Christoffersen, K. (eds.) The Structuring Role of Submerged Macrophytes in Lakes. Ecological Studies, 131, 339352. DOI: 10.1007/978-1-4612-0695-8 25

Venturi, S., Franceso, S. D., Materazzi F. \& Manciola, P. (2016). Unmanned aerial vehicles and Geographical Information System integrated analysis of vegetation in Trasimeno Lake, Italy. Lakes and Reservoirs, Research and Management, 21, 5-19. DOI: 10.1111/lre.12117

Verhoeven, J. T. A. (2009). Wetland biogeochemical cycles and their interaction. In Maltby E, Barker T (eds.) The Wetlands Handbook, pp. 266-281. DOI: 10.1002/9781444315813.ch12 Vicente, E., Rodrigo, M. A., Camacho, A. \& Mir- acle, M. R. (1991). Phototrophic prokaryotes in a karstic sulphate lake. Verhandlungen Internationale Vereinigung für theoretische und angewandte Limnologie, 24, 998-1004.

Weeks, S. J., Currie, B. \& Bakun, A. (2002). Satellite imaging. Massive emissions of toxic gas in the Atlantic. Nature, 415, 493-494. DOI: $10.1038 / 415493 b$

Westman, P., Borgendahl, J., Bianchi, T. S. \& Chen, N. (2003). Probable Causes for Cyanobacterial Expansion in the Baltic Sea; Role of Anoxia and Phosphorus Retention. Estuaries, 26, 680-689. DOI: 10.1007/BF02711979

Woodget, A., Austrums, R., Maddock, I. P. \& Habit, E. (2017) Drones and digital photogrammetry, from classifications to continuums for monitoring river habitat and hidromorphology. WIREs Water, 4, e1222. DOI: $10.1002 /$ wat2.1222

Zhang, C. \& Kovacs, J. M. (2012). The application of small unmanned aerial systems for precision agriculture, A review. Precision Agriculture, 13, 693-712. DOI: 10.1007/s11119012-9274-5 